\title{
Development and validation of a 3D printed antiviral ventilator filter - a comparative study
}

\author{
Ruth Shaylor ${ }^{1}$, Mathew Francis ${ }^{2}$, Esther Shaylor ${ }^{3}$, Solomon Dadia ${ }^{4,5}$ and Barak Cohen ${ }^{1,6^{*}}$
}

\begin{abstract}
Background: The current coronavirus infectious disease 2019 (COVID-19) pandemic has caused unexpected pressure on medical supplies, interrupting supply chains and increasing prices. The supply of antiviral filters which form an essential part of the ventilator circuit have been affected by these issues. Three-dimensional (3D) printing may provide a solution to some of these issues.

Methods: We designed and tested 3D printed heat and moisture exchange (HME) and antiviral casing. For each casing we tested two different filter materials derived from a sediment water filter cartridge or 1.5- $\mu \mathrm{m}$ glass fiber filter paper. A polyurethane sponge was used for the HME. Each design was tested for circuit leak, circuit compliance, peak inspiratory pressure and casing integrity using methylene blue dye.

Results: We designed, produced, and tested two different types of antiviral filters with six different internal configurations. Overall, we tested 10 modified filter designs and compared them with the original commercial filter. Except for the combination of 1.5- $\mu \mathrm{m}$ filter paper and $5 \mathrm{~mm}$ sponge peak inspiratory pressure and circuit compliance of the filters produced were within the operating limits of the ventilator. All In addition, all filters passed the dye test.

Conclusions: Our filter may be of particular importance to those working in low middle-income countries unable to compete with stronger economies. Our design relies on products available outside the healthcare supply chain, much of which can be purchased in grocery stores, hardware stores, or industrial and academic institutions. We hope that these HMEs and viral filters may be beneficial to clinicians who face critical supply chain issues during the COVID-19 pandemic.
\end{abstract}

Keywords: COVID-19, 3D printing, Anesthesia, Ventilator, Global Health

\section{Background}

The recent coronavirus infectious disease 2019 (COVID19) pandemic caused by the severe acute respiratory syndrome coronavirus 2 (SARS-CoV-2) originated in China in late 2019, and has since spread to most of the world,

\footnotetext{
* Correspondence: BarakC@tlvmc.gov.il

'Division of Anesthesia, Intensive Care, and Pain Management, Tel-Aviv Medical Center; Tel-Aviv University, 6 Weizmann Street, 6423906 Tel-Aviv, Israel

${ }^{6}$ Outcomes Research Consortium, Cleveland Clinic, Cleveland, OH, USA Full list of author information is available at the end of the article
}

affecting millions and overwhelming health systems globally. Aside from the extreme effects on global economy and healthcare, the pandemic also caused an unexpected surge in demand of certain health-related supplies, unmet by existing supply chains $[1,2]$. In particular items related to respiratory support and mechanical ventilation are among those in high demand.

This has led to an unprecedented amount of bartering with suppliers and export bans for certain items [3, 4]. Countries with relatively small purchasing power or

(c) The Author(s). 2021 Open Access This article is licensed under a Creative Commons Attribution 4.0 International License, which permits use, sharing, adaptation, distribution and reproduction in any medium or format, as long as you give appropriate credit to the original author(s) and the source, provide a link to the Creative Commons licence, and indicate if changes were made. The images or other third party material in this article are included in the article's Creative Commons licence, unless indicated otherwise in a credit line to the material. If material is not included in the article's Creative Commons licence and your intended use is not permitted by statutory regulation or exceeds the permitted use, you will need to obtain permission directly from the copyright holder. To view a copy of this licence, visit http://creativecommons.org/licenses/by/4.0/ The Creative Commons Public Domain Dedication waiver (http://creativecommons.org/publicdomain/zero/1.0/) applies to the data made available in this article, unless otherwise stated in a credit line to the data. 
those considered to be of low and middle income (LMIC) have been "priced out" of the market.

Filters form an essential part of the breathing circuit of mechanical ventilators, protecting their internal parts from various pathogens. In the intensive care unit (ICU) they are usually replaced every $24 \mathrm{~h}$ or earlier if they become clogged. In the operating room (OR) they should be replaced after each case. A filter rated for bacterial pathogens is normally sufficient. Under the current circumstances, however, the filter material needs to be dense enough to protect against viral pathogens and small aerosolized particles [5].

Three-dimensional (3D) printing has drawn attention as a potential temporary solution due to its flexibility and reproducibility. Once an item has been developed as an electronic stereolithography (STL) file it can be produced anywhere in the world with access to the right type of 3D printer. This has enabled hospitals and universities to print many items in house as well as an army of volunteers who have a home desktop 3D printer. The majority of these efforts have focused on personal protective equipment (PPE) or the development or modification of ventilators [6-8]. To date, there have been no media reports or publications on the development of 3D printed antiviral filters for use on anesthesia machines or ventilators, despite them forming an essential component in the care of COVID-19 patients.

Tel Aviv Medical Center (TLVMC) has gained experience in using $3 \mathrm{D}$ modelling and printing on perioperative planning [9-11]. Considering possible difficulties in acquiring antiviral filters during the current pandemic, this experience was utilized to meet the potential shortage, as a last life-saving resort in case of commercial supply-chain failure.

We hereby describe our experience in designing, developing, producing, and testing of an alternative $3 \mathrm{D}$ printed viral filter for use in ventilator breathing circuits. We also share the specific files needed to reproduce our design, and the specific materials we used and tested. Lastly, we describe the methodology and results of the comparative validation tests we used to verify the feasibility of using our printed filter, compared to commercially available models.

\section{Methods}

This was a single center feasibility study utilizing international multidisciplinary collaboration aimed at comparing the technical characteristics of various air filter designs. No patients were involved, and ethical review board was therefore deemed unnecessary.

\section{Filter material}

After discussion with a filtration engineer (MF) it was decided to test a sediment cartridge normally used in home water filtration systems (Noga Watercare B.V., The Netherlands) rated at $5 \mu \mathrm{m}$, and $1.5 \mu \mathrm{m}$ glass fiber filter paper (934-AH, Whatman, GE Healthcare, UK). The outer layer of the filter was peeled off, leaving a strip $1 \mathrm{~mm}$ thick. Using an existing heat and moisture exchange (HME) filter (Intersurgical, UK) that had been carefully taken apart as a template, a circle of the filter material was cut. This was then placed inside the existing HME and testing was carried out as described below.

Some of the required materials were easily available from retail stores. However, $1.5 \mu \mathrm{m}(\mu \mathrm{m})$ filter paper was not available in stores or through local distributors. Eventually, we were able to receive this item from a local water treatment facility (Ayalon Water Treatment Plant, Ramla, Israel).

\section{Heat moisture exchange material}

The foam in the commercial HME is $6 \mathrm{~mm}$ thick and has a similar density to commercially available polyurethane sponges (Scotch-brite, $3 \mathrm{M}$, USA) [12]. These were purchased from a local vendor and the abrasive part was removed. Using the HME as a template, discs of approximately $5 \mathrm{~mm}$ and $2 \mathrm{~mm}$ thickness were cut. The sponge discs were subsequently inserted into a commercial HME filter instead of the original sponge and tested on an anesthesia machine for inspiratory pressure, circuit compliance and circuit leak as described below.

\section{D design}

A commercial HME filter (Intersurgical, UK) was measured using a computerised calibre (Fujifilm, Japan) by design engineers (Synergy3DMed, Netanya, Israel). These measurements were then transferred to a computer assisted design program (SP5.0 SolidWorks 2019, Dassault Système, USA) to build the model. After building the digital model, it was adapted to print on Stratasys J750 "Objet" printer (Stratasys, Israel) that allows simultaneous printing of multiple materials. The design was printed on the high mix setting using the biocompatible polymer Med610 filament (Stratasys, Israel). A similar process was repeated to design a $3 \mathrm{D}$ model of a commercial viral filter (Intersurgical, UK), that has no HME capabilities.

\section{Circuit compliance and leak testing}

Discs of the various filter materials were placed inside the viral filter casing and inspiratory pressure, circuit compliance, and circuit leak were tested. A similar process was conducted for the HME but with the sponge inserts as well as the filter material. The materials used were compared to a commercially available HME filter at each stage of the filter design for circuit leak and compliance. All tests were carried out on the same 
Perseus A500 anesthesia machine (Drager, Lubeck, Germany).

The following tests were performed:

- The adjustable pressure valve (APL) was set to $30 \mathrm{cmH}_{2} \mathrm{O}$. Using the auto leak test function, the filter was tested for circuit leak and circuit compliance.

- The APL was then opened.

- The filter was then attached to a $2000 \mathrm{ml}$ test lung and the ventilator was set to a tidal volume of 520 $\mathrm{ml}$, respiratory rate 12 breaths per minute and positive end-expiratory pressure (PEEP) of $3 \mathrm{cmH}_{2} 0$. Gas flow was decreased to 11 per minute. Peak inspiratory pressures were recorded.

The following combinations were evaluated:

- Commercial HME

- Commercial HME case, sediment filter cartridge

- Commercial HME case, $1.5 \mu \mathrm{m}$ filter paper

- Commercial HME case, $5 \mathrm{~mm}$ sponge

- Commercial HME case, 2 mm Sponge

- 3D printed HME, Sediment filter cartridge, $5 \mathrm{~mm}$ sponge

- 3D printed HME, Sediment filter cartridge, $2 \mathrm{~mm}$ sponge

- 3D printed HME, $1.5 \mu \mathrm{m}$ filter paper, $5 \mathrm{~mm}$ sponge

- 3D printed HME, $1.5 \mu \mathrm{m}$ filter paper, $2 \mathrm{~mm}$ sponge

- 3D printed viral filter, sediment filter cartridge

- 3D printed viral filter, $1.5 \mu \mathrm{m}$ filter paper

All tests were conducted 3 times for each combination, and the "worst" results are reported.

\section{Internal filter integrity testing}

To confirm the integrity of the filter, a transfer medium was used to determine if any voids were present in the completed filter. Aqueous methylene blue (Sterop NV, Belgium) was diluted to a concentration of $0.05 \mathrm{mg} / \mathrm{ml}$ and used as a dye. Fifty $\mathrm{ml}$ of the dye were passed through the filter from the expiratory side. The exterior of the filter was visually examined for leaks. Following the test, the filter was taken apart and the spread of the dye on the filter material was visually inspected. If a clear margin was observed on the filter paper where the dye had not spread to parts of the filter casing, it was assumed that the transfer medium had passed through the filter and not around it $[13,14]$. Therefore, it was assumed that filters which passed this test would have air flowing through the filter paper once connected to the anesthesia machine (Fig. 1).

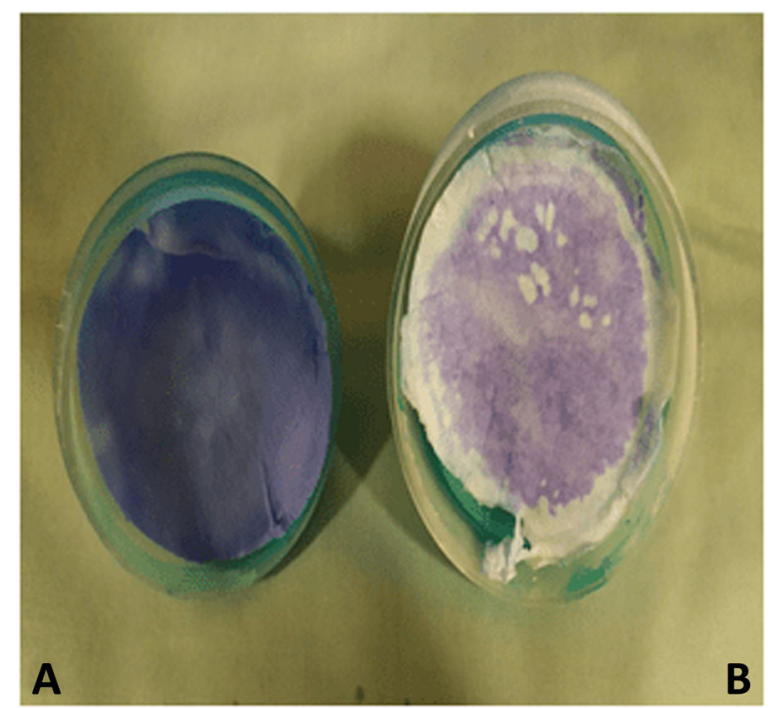

Fig. 1 Illustration of the dye leak test. a $1.5 \mu \mathrm{m}$ filter paper with dye leaking around the edges. b $1.5 \mu \mathrm{m}$ filter paper where all the dye has passed through the filter material without leaking around the edges

\section{Results}

We were able to design, produce, and test two different types of antiviral filters with six different internal configurations (Fig. 2). Overall, we tested 10 modified filter designs and compared them with the original commercial type. The results of the static pressure leak test, compliance, and peak pressures, as well as the dye leakage test, are presented in Table 1.

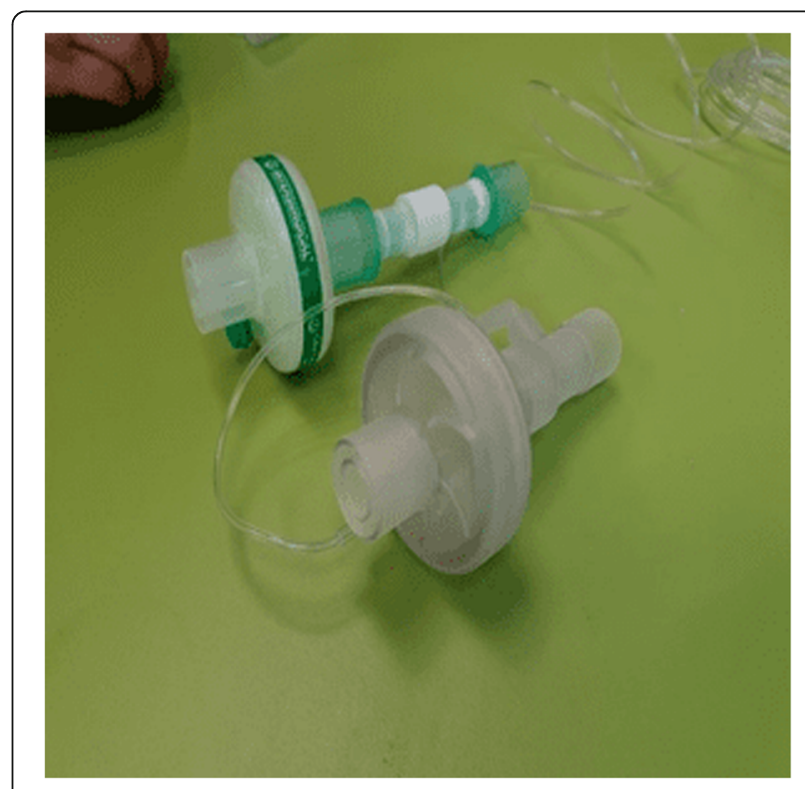

Fig. 2 The commercial (upper side, Intersurgical, UK) and 3D printed HME filters 
Table 1 Test results of 10 filter designs from leak tests performed on a Perseus A500 anesthesia machine (Drager, Lubeck, Germany)

\begin{tabular}{|c|c|c|c|c|}
\hline Device & $\begin{array}{l}\text { Circuit leak } \\
(\mathrm{ml} / \mathrm{min})\end{array}$ & $\begin{array}{l}\text { Circuit Compliance } \\
\left(\mathrm{ml} / \mathrm{cmH}_{2} \mathrm{O}\right)\end{array}$ & $\begin{array}{l}\text { Peak inspiratory pressure } \\
\left(\mathrm{cmH}_{2} \mathrm{O}\right)\end{array}$ & Adequate dye test \\
\hline Commercial HME & 10 & 1.3 & 19 & NA \\
\hline Commercial HME, sediment filter cartridge & 10 & 1.4 & 23 & NA \\
\hline Commercial HME, $1.5 \mu \mathrm{m}$ filter paper & 44 & 1.5 & 19 & NA \\
\hline Commercial HME, $5 \mathrm{~mm}$ sponge & 43 & 1.4 & 21 & NA \\
\hline Commercial HME, 2 mm Sponge & 80 & 1.5 & 20 & NA \\
\hline 3D printed $\mathrm{HME}$, Sediment filter cartridge, $5 \mathrm{~mm}$ sponge & 69 & 1.4 & 20 & Yes \\
\hline 3D printed $\mathrm{HME}$, Sediment filter cartridge, $2 \mathrm{~mm}$ sponge & 70 & 1.4 & 19 & Yes \\
\hline 3D printed $\mathrm{HME}, 1.5 \mu \mathrm{m}$ filter paper, $5 \mathrm{~mm}$ sponge & 15 & 1.4 & 27 & Yes \\
\hline $3 \mathrm{D}$ printed $\mathrm{HME}, 1.5 \mu \mathrm{m}$ filter paper, $2 \mathrm{~mm}$ sponge & 35 & 1.5 & 22 & Yes \\
\hline 3D printed viral filter, sediment filter cartridge & 67 & 1.4 & 20 & Yes \\
\hline 3D printed viral filter, $1.5 \mu \mathrm{m}$ filter paper & 29 & 1.4 & 23 & Yes \\
\hline
\end{tabular}

Leak compliance and peak pressure tests were conducted 3 times, and the wort result is reported, $3 D$ three-dimensional, $H M E$ heat and moisture exchanger, NA not applicable

The maximal leak among all combinations was $80 \mathrm{ml} /$ min, which is well below the upper allowed limit of the anesthesia station examined $(150 \mathrm{ml} / \mathrm{min})$. The circuit compliance did not change significantly compared to the reference filter (maximal compliance of $1.5 \mathrm{ml} / \mathrm{cmH}_{2} \mathrm{O}$ compared to the $1.3 \mathrm{ml} / \mathrm{cmH}_{2} \mathrm{O}$ reference). Similar results were found for the peak inspiratory pressure, with a maximum of $27 \mathrm{cmH}_{2} \mathrm{O}$ compared to a reference of 19 $\mathrm{cmH}_{2} \mathrm{O}$. Of note, the 3D printed filters did not result in any variable outside the acceptable range [15]. All filters passed the dye test.

\section{Discussion}

We successfully designed and tested an antiviral and HME filter with 3D printed casing in 1 week. We produced two versions of each filter using different filter materials. Except for the combination of $1.5 \mu \mathrm{m}$ filter paper and $5 \mathrm{~mm}$ sponge, which had an unacceptably high peak inspiratory pressure, both produced circuit leak and compliance tests within the normal operating limits of the anesthesia machine they were tested on [15].

Healthcare systems around the globe are currently experiencing unforeseen demand of medical items. To mitigate the impact of this shortage on LMICs we used simple materials accessible outside the normal hospital supply chain to successfully develop and test 3D printed HMEs and viral filters for use on anesthesia machines and ventilators. These casings have been trialed to resemble the properties of those available commercially.

COVID-19 spreads via aerosolization and contact with contaminated surfaces [16]. Aerosols occur when solid or liquid molecules are dispersed through air. Their size can range from $0.3-100 \mu \mathrm{m}$ in diameter. Particles of $1-$ $5 \mu \mathrm{m}$ remain in the air and therefore, present the biggest challenge [5]. Considering this method of transmission, appropriate filtration of ventilator circuits is of vital importance [17].

The antiviral properties of $1.5 \mu \mathrm{m}$ filter paper have been previously investigated $[18,19]$. Whilst more effective at trapping larger particles $(1.5 \mu \mathrm{m})$ they are effective at trapping particles as small as $0.3 \mu \mathrm{m}$, particularly at highly humid environments as found in the $\operatorname{HME}[5,20]$. The $1.5 \mu \mathrm{m}$ filter paper is usually used by water processing plants, and in food and drink manufacturing. As a relatively specialist material, it may not be readily available.

The antiviral properties of the $5 \mu \mathrm{m}$ sediment cartridge have been less well investigated. The pore size of this material seems too large. Nevertheless, this is the pore size when the material is saturated with water. When used in air, the pore size is one-tenth the size in water [21]. This would provide a pore size of $0.5 \mu \mathrm{m}$, which should be sufficient. It is also more widely available and easier to source, in case the $1.5 \mu \mathrm{m}$ filter paper is unavailable. The product we used is also available as a $1-\mu \mathrm{m}$ sediment cartridge which is suitable as an antiviral filter [22].

The humidifying properties of a foam-based HME depend on the foam's density. Humidification capability is proportional to density, but it increases resistance to air flow. The density of the foam used in the commercial HME is $26-32 \mathrm{~kg} \mathrm{~m}^{-3}$ [23]. We calculated the density of the foam we used gravimetrically as $21 \mathrm{~kg} \mathrm{~m}^{-3}$. The porosity of the foam was calculated as $98 \%$ which is in line with previous studies of polyurethane foams [24, 25]. It is not unreasonable, therefore, to expect that both foams will produce similar humidification at standard operating room conditions.

Another potential advantage to our filter is that it can be disassembled and the $3 \mathrm{D}$ printed parts re-sterilized using either commercially available wipes or by soaking in bleach. Once dry, the filter and HME material can be replaced and it can be reused. 
We have completed the feasibility and suitability tests demonstrating that the different filters comply with the anesthesia machine specifications. However, we did not evaluate their actual antiviral, antibacterial, and heat and moisture preservation capabilities and further investigations in this area should be considered prior to use. Nevertheless, all designs passed the methylene-blue dye test demonstrating that the dye passed through the filter rather than around it. This is similar to most 3D printed N95 masks reported in the literature which have at best undergone leak testing but no further clinical evaluation.

It should be pointed out, however, that these filters are only intended for use as a last resort to overcome an abrupt interruption of the supply chain, rather than to replace commercial alternatives. As a class II medical device, we would strongly encourage anyone planning on using our design to apply for an Emergency Use Approval from their relevant regulatory body.

Whilst production of designs in the healthcare setting suitable for 3D printing requires a certain amount of technical skills, reproducing them in the field does not $[26,27]$. With mobile data being nearly ubiquitous, an internet connection is no longer required in order to share models with colleagues working in low resource or rural settings. STL files are relatively small $(2-70$ megabytes $[\mathrm{Mb}])$, and can be printed in geographically remote locations with no internet access using a mobile phone, laptop, SD card, and a 3D printer. The whole process requires about $600 \mathrm{Mb}$ of data storage. We have also printed these filters using polylactic acid (PLA) and polyvinyl alcohol (PVA) filler on a desktop Makerbot Method printer (Stratasys, Minnesota, USA). One cartridge of PLA will make approximately 9-13 filters. The STL file we produced is available as Supplemental Material to this report.

In these tumultuous times, it is a responsibility of the international medical community to provide assistance to our colleagues who are experiencing shortage of equipment, either through a disrupted supply chain or by being priced out of the market. We hope that these HMEs and viral filters may be of use to clinicians who may face critical supply chain issues during the COVID-19 pandemic.

\section{Abbreviations}

3D: Three-dimensional; COVID-19: Coronavirus infectious disease 2019; HME: Heat and moisture exchange; ICU: Intensive care; LMIC: Low and middle income country; OR: Operating room; PEEP: Positive end-expiratory pressure; PLA: Polylactic acid; PPE: Personal protective equipment; PVA: Polyvinyl alcohol; SARS-CoV-2: Severe acute respiratory syndrome coronavirus 2; STL: Stereolithography; TLVMC: Tel Aviv Medical Center
}

\section{Supplementary Information}

The online version contains supplementary material available at https://doi. org/10.1186/s12871-021-01310-z.

Additional file 1.

\section{Acknowledgements}

The Authors would like to thank Meiron Cramer, Isaac Howser and the staff at the Ayalon Waste Water Treatment Facility for their help in sourcing different filter materials. We would also like to thank the Synergy3DMed for their assistance with the filter casing design.

\section{Authors' contributions}

RS - was involved in designing the study, collecting and analyzing the data and writing the manuscript. They are the guarantor for the study. MF- was involved in designing the study, analyzing the data and writing the manuscript. ES - was involved in designing the study, analyzing the data and writing the manuscript. SD - was involved in designing the study, collecting and analyzing the data and writing the manuscript. BC - was involved in designing the study, collecting and analyzing the data and writing the manuscript. The authors read and approved the final manuscript.

\section{Funding}

This study was supported by departmental and institutional resources only.

\section{Availability of data and materials}

The datasets used and/or analysed during the current study are available from the corresponding author on reasonable request.

\section{Declarations}

Ethics approval and consent to participate Not applicable.

\section{Consent for publication}

Not applicable.

\section{Competing interests}

The authors declare that they have no competing interests.

\section{Author details}

'Division of Anesthesia, Intensive Care, and Pain Management, Tel-Aviv Medical Center; Tel-Aviv University, 6 Weizmann Street, 6423906 Tel-Aviv, Israel. ${ }^{2}$ Department of Food Science, University of Leeds, Leeds, UK. ${ }^{3}$ Supply Division, United Nations Children's Fund, Copenhagen, Denmark. ${ }^{4}$ Surgical 3D printing Laboratory, Tel-Aviv Medical Center, Tel-Aviv, Israel. ${ }^{5}$ Department of Orthopedic Oncology, Tel-Aviv Medical Center, Tel-Aviv University,

Tel-Aviv, Israel. ${ }^{6}$ Outcomes Research Consortium, Cleveland Clinic, Cleveland, $\mathrm{OH}$, USA.

Received: 1 December 2020 Accepted: 16 March 2021

Published online: 14 April 2021

\section{References}

1. FAQs on Shortages of Surgical Masks and Gowns. https://www.fda.gov/ medical-devices/personal-protective-equipment-infection-control/faqsshortages-surgical-masks-and-gowns. Accessed 1 Oct 2020.

2. Shortage of personal protective equipment endangering health workers worldwide. https://www.who.int/news-room/detail/03-03-2020-shortage-ofpersonal-protective-equipment-endangering-health-workers-worldwide.

3. COVID-19: Trade and trade-related measures. https://www.wto.org/english/ tratop_e/covid19_e/trade_related_goods_measure_e.htm. Accessed 1 Oct 2020.

4. In Desperation, New York State Pays Up to 15 Times the Normal Prices for Medical Equipment. https://www.propublica.org/article/in-desperation-newyork-state-pays-up-to-15-times-the-normal-price-for-medical-equipment. Accessed 1 Oct 2020.

5. Wang J, Du G. COVID-19 may transmit through aerosol. Ir J Med Sci. 2020;189(4):1143-44. https://doi.org/10.1007/s11845-020-02218-2.

6. Clarke AL. 3D printed circuit splitter and flow restriction devices for multiple patient lung ventilation using one anaesthesia workstation or ventilator. Anaesthesia. 2020;75(6):819-20. https://doi.org/10.1111/anae.15063 Accessed 1 Oct 2020.

7. Coronavirus: 3D-printer owners rally to create NHS face masks. https://www. bbc.com/news/technology-52111522. Accessed 1 Oct 2020. 
8. 3D PRINTING COMMUNITY RESPONDS TO COVID-19 AND CORONAVIRUS RESOURCES https://3dprintingindustry.com/news/3d-printing-communityresponds-to-covid-19-and-coronavirus-resources-169143/.

9. Ungar OJ, Handzel O, Haviv L, Dadia S, Cavel O, Fliss DM, et al. Optimal head position following Intratympanic injections of steroids, as determined by virtual reality. Otolaryngol Head Neck Surg. 2019;161(6):1012-7. https:// doi.org/10.1177/0194599819878699.

10. Ankory R, Kadar A, Netzer D, Schermann H, Gortzak Y, Dadia S, et al. 3D imaging and stealth navigation instead of $\mathrm{CT}$ guidance for radiofrequency ablation of osteoid osteomas: a series of 52 patients. BMC Musculoskelet Disord. 2019;20(1):579. https://doi.org/10.1186/s12891-019-2963-8.

11. Ungar OJ, Dadia S, Yahav O, Handzel O, Fliss DM, Cavel O. Tri-dimensional model for ventilation tube permeability. Eur Arch Oto Rhino Laryngol. 2018; 275(11):2627-32.

12. HME Foams. https://www.technicalfoamservices.co.uk/product/hme-foams/. Accessed 1 Oct 2020.

13. Moghimi N, Park S-I. Leakage assessment of flexible pouches using dye penetration test with correlation to modeled bacterial aerosol challenge test. Food Sci Biotechnol. 2017;26(4):947-53. https://doi.org/10.1007/s10068017-0134-y

14. Guo H, Wyart Y, Perot J, Nauleau F, Moulin P. Low-pressure membrane integrity tests for drinking water treatment: a review. Water Res. 2010;44(1): 41-57. https://doi.org/10.1016/j.watres.2009.09.032.

15. Drager. Instructions for use Perseus A500. Lubeck: Dragerwerk AG \& Co. KGaA; 2017.

16. van Doremalen N, Bushmaker T, Morris DH, Holbrook MG, Gamble A, Williamson BN, et al. Aerosol and surface stability of SARS-CoV-2 as compared with SARS-CoV-1. N Engl J Med. 2020;382:1564-7.

17. Cook TM, El-Boghdadly K, McGuire B, McNarry AF, Patel A, Higgs A. Consensus guidelines for managing the airway in patients with COVID-19. Anaesthesia. 2020;75:785-99.

18. Wang $M$, Brion $\mathrm{G}$. Effects of RH on glass microfiber filtration efficiency for airborne Bacteria and bacteriophage over time. Aerosol Sci Technol. 2007; $41(8): 775-85$. https://doi.org/10.1080/02786820701455351.

19. McMinn BR, Korajkic A. A small volume procedure for viral concentration from water. J Vis Exp. 2015;96:51744.

20. Harstad JB, Decker HM, Buchanan LM, Filler ME. Air filtration of submicron virus aerosols. Am J Public Health Nations Health. 1967;57(12):2186-93. https://doi.org/10.2105/AJPH.57.12.2186.

21. Olson WP, Vanden Houten L, Ellis JE. Sterile vent filter function test. J Parenteral Sci Technol. 1981;35(2):70-1.

22. Metreveli G, Wågberg L, Emmoth E, Belák S, Strømme M, Mihranyan A. A size-exclusion Nanocellulose filter paper for virus removal. Adv Healthc Mat. 2014:3(10):1546-50. https://doi.org/10.1002/adhm.201300641.

23. Turnbull D, Fisher PC, Mills GH, Morgan-Hughes NJ. Performance of breathing filters under wet conditions: a laboratory evaluationt. BJA. 2005; 94(5):675-82. https://doi.org/10.1093/bja/aei091.

24. Hodlur RM, Rabinal MK. Self assembled graphene layers on polyurethane foam as a highly pressure sensitive conducting composite. Compos Sci Technol. 2014:90:160-5. https://doi.org/10.1016/j.compscitech.2013.11.005.

25. Sotelo TJ, Satoh H, Mino T. Effect of sponge media structure on the performance of the intermittent contact oxidation process for in-sewer purification. Biochem Eng J. 2019;149:107254. https://doi.org/10.1016/j.bej.2 019.107254.

26. Streamlining Humanitarian Aid with Additive Manufacturing at Oxfam https://rctom.hbs.org/submission/streamlining-humanitarian-aid-with-a dditive-manufacturing-at-oxfam/. Accessed 1 Oct 2020.

27. USING 3D PRINTING FOR WASH PRODUCTS - WHAT WE FOUND. https:// www.elrha.org/project-blog/using-3d-printing-for-wash-products-what-wefound/. Accessed 1 Oct 2020.

\section{Publisher's Note}

Springer Nature remains neutral with regard to jurisdictional claims in published maps and institutional affiliations.

Ready to submit your research? Choose BMC and benefit from:

- fast, convenient online submission

- thorough peer review by experienced researchers in your field

- rapid publication on acceptance

- support for research data, including large and complex data types

- gold Open Access which fosters wider collaboration and increased citations

- maximum visibility for your research: over $100 \mathrm{M}$ website views per year

At $\mathrm{BMC}$, research is always in progress.

Learn more biomedcentral.com/submissions 